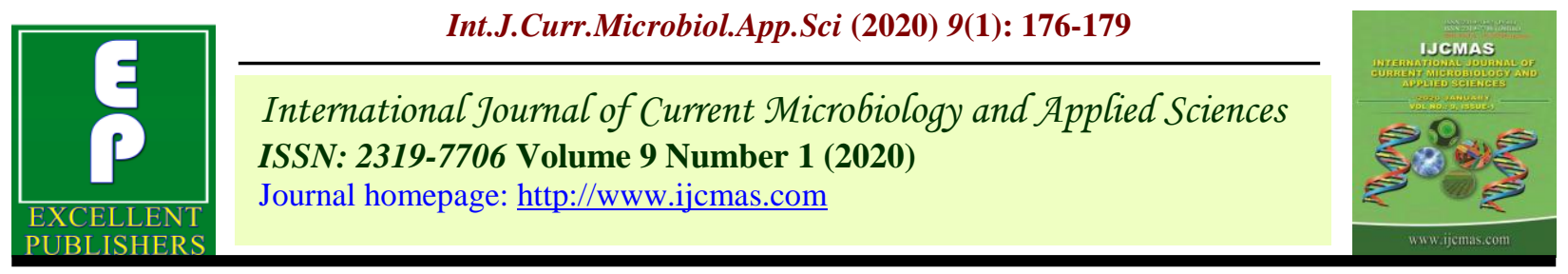

Original Research Article

https://doi.org/10.20546/ijcmas.2020.901.020

\title{
Economic Impact of Goat Farming on Livelihood of Goat Farmers of Nabarangpur District of Odisha, India
}

\author{
M. Mohanty, B. C. Das* and S. M. Nanda \\ Department of Veterinary and Animal Husbandry Extension, College of Veterinary Science \\ and Animal Husbandry, OUAT, Bhubaneswar \\ *Corresponding author
}

\section{Keywords}

Economic impact, Livelihood, Goat farming

Article Info

Accepted:

15 December 2019

Available Online:

20 January 2020

\section{A B S T R A C T}

The present investigation was carried out in two blocks of Nabarangpur district of Odisha. 120 respondents were selected randomly having minimum 10 numbers of goats with 5 years of experience in goat rearing. The overall mean score (34.43) of economic impact showed a positive sign for the economic prosperity. The study revealed that $69 \%$ of the respondents had medium level of economic impact due to goat farming followed by $18 \%$ and $13 \%$ respondents with high level and low level of economic impacts respectively. The economic success of goat husbandry depends on the availability of resources within the household. So, Government should take steps to popularize goat rearing in mass media, regular training and exposure visits to nearby successful farms and provide necessary financial support to the farmers. Some scientific practices must be followed in order to enhance the economic growth of the goat farmers.

\section{Introduction}

The economic contribution of small ruminants to poor farm households and livelihood systems is high. Goats are one of the economically important livestock in world. They play an important role in the livelihood of resource poor farmers. They provide their owners with a vast range of products and services such as meat, milk, skin, hair, horns, bones, manure and urine for cash. Goat farming constitutes the means of livelihood of over 25 per cent of Odisha's rural population. Goats are reared predominantly by the landless and marginal farmers and to a lesser extent by the small farmers too (together some 80 per cent), as a means of livelihood. Odisha is also famous for the native germplasm like Ganjam, Black Bengal, Raighar, Badavihana. These breeds are unique in nature and adapt to 
the local situation very well. Studies by various authors indicate that the goat rearing enterprise made significant contribution to the economic welfare of poor people and creation of employment opportunities to rural people (Ahmad,2015 ;Manzi, et al.,2013and Soni, et al., 2011)

\section{Materials and Methods}

The study was conducted in two different blocks of Nabarangpur district of Odisha. The blocks namely Papdahandi and Raighar were selected at random. From each block, 12 Gram Panchanchayats (GPs) were selected at random and from each GP, one village was randomly selected. Thereafter, five respondents with minimum 10 numbers of goats and with five years of experience in goat farming were selected from each village. Thus, a total of 120 respondents were selected. Data were collected through personal interview method and appropriate statistical analysis was done to draw the inferences.

\section{Results and Discussion}

Response of respondents to the statements on economic impact is depicted in Table I. Analysis of data relating to economic impact on the farmers revealed that 45.8 percent of the respondent have seen an increase in personal savings in the bank account due to increased income from goat farming. $72.55 \%$ of the respondents agreed that they have constructed semi pucca/pucca house on their own land through goat rearing. The earning from goat rearing has increased the ability of $54.1 \%$ of the respondents to spend the required amount for their children's education. Similarly, $73.3 \%$ of the respondents that their ability to spend for emergency medical care of the family members due to their goat business. The study also revealed that the respondents (79.1\%) spending on food items has also increased due to goat rearing. Goat farming was able to help $45 \%$ of the respondents to increase their spending on clothing. $84.1 \%$ of the respondents had repaid the loan borrowed from money lenders. They credit goat farming for this success. This proved to be very encouraging. It was also reported that due to goat farming, $48.3 \%$ of the respondents were lending money on credit to others. It was found out that $53.3 \%$ of the respondents had the required ability to add additional goats to their existing farm. $50 \%$ of the goat farmers taken for study agreed to the fact that their profit has increased due to goat farming whereas $33.3 \%$ did not agree to this, keeping the mean score at 3.2.The overall mean score of economic impact on beneficiaries was 34.43 which is a positive sign for the economic prosperity. Similar type of findings was reported by different authors in their studies related to impact of goat rearing on the livelihood of farmers (Ahmad, et al., 2015; Budisatria et al.,2013; Teufelet al.,1998)

The analysis of distribution of respondents as per economic impact revealed that there is high level of economic impact on $18 \%$ of the beneficiaries while medium level of impact is on $69 \%$ of the beneficiaries. The economic success of goat husbandry depends on the availability of resources within the household i.e. land, livestock, labour, off-farm income.

Overall analysis of economic impact revealed that there is increase in the level of income of the goat farmers from goat rearing so that they were able to construct house, save money in the banks, purchase goats for expansion of the farm. 
Table.1 Response of respondents to the statements on economic impact

\begin{tabular}{|c|c|c|c|c|c|c|c|}
\hline \multirow{2}{*}{$\begin{array}{l}\text { Sl } \\
\text { No }\end{array}$} & \multirow[t]{2}{*}{ Statements } & \multicolumn{5}{|c|}{ Response } & \multirow[t]{2}{*}{ Mean } \\
\hline & & SA & A & UD & DA & SD & \\
\hline $\mathbf{1}$ & Increased in personal savings in bank account & $\begin{array}{c}2 \\
1.66\end{array}$ & $\begin{array}{c}55 \\
45.8\end{array}$ & $\begin{array}{c}15 \\
12.5\end{array}$ & $\begin{array}{l}48 \\
40\end{array}$ & $\begin{array}{l}0 \\
0\end{array}$ & 3.09 \\
\hline 2 & $\begin{array}{l}\text { Constructed /renovated a pucca /semipucca } \\
\text { house on my own land from the profit of goat } \\
\text { business }\end{array}$ & $\begin{array}{c}1 \\
0.83\end{array}$ & $\begin{array}{c}87 \\
72.5\end{array}$ & $\begin{array}{c}7 \\
5.8\end{array}$ & $\begin{array}{c}25 \\
20.8\end{array}$ & $\begin{array}{l}0 \\
0\end{array}$ & 3.53 \\
\hline 3 & $\begin{array}{c}\text { Able to spend money for my children } \\
\text { education }\end{array}$ & $\begin{array}{c}1 \\
0.83\end{array}$ & $\begin{array}{c}65 \\
54.1\end{array}$ & $\begin{array}{c}26 \\
21.6\end{array}$ & $\begin{array}{c}28 \\
23.3\end{array}$ & $\begin{array}{l}0 \\
0\end{array}$ & 3.32 \\
\hline 4 & $\begin{array}{l}\text { Able to spend money for emergency medical } \\
\text { care of my family members }\end{array}$ & $\begin{array}{c}1 \\
0.83\end{array}$ & $\begin{array}{c}88 \\
73.3\end{array}$ & $\begin{array}{c}10 \\
8.33\end{array}$ & $\begin{array}{c}21 \\
17.5\end{array}$ & $\begin{array}{l}0 \\
0\end{array}$ & 3.57 \\
\hline 5 & $\begin{array}{c}\text { My spending on food items has increased than } \\
\text { before }\end{array}$ & $\begin{array}{c}1 \\
0.83\end{array}$ & $\begin{array}{c}95 \\
79.1\end{array}$ & $\begin{array}{c}15 \\
12.5\end{array}$ & $\begin{array}{c}19 \\
15.8\end{array}$ & $\begin{array}{l}0 \\
0\end{array}$ & 3.9 \\
\hline 6 & $\begin{array}{l}\text { Now I am able to spend more on clothings of } \\
\text { my family members }\end{array}$ & $\begin{array}{c}2 \\
1.66\end{array}$ & $\begin{array}{l}54 \\
45\end{array}$ & $\begin{array}{c}62 \\
51.6\end{array}$ & $\begin{array}{c}2 \\
1.6\end{array}$ & $\begin{array}{l}0 \\
0\end{array}$ & 3.46 \\
\hline 7 & $\begin{array}{l}\text { Now I am not borrowing money from private } \\
\text { money lenders }\end{array}$ & $\begin{array}{c}3 \\
2.5\end{array}$ & $\begin{array}{l}101 \\
84.1\end{array}$ & $\begin{array}{c}13 \\
10.8\end{array}$ & $\begin{array}{c}3 \\
2.5\end{array}$ & $\begin{array}{l}0 \\
0\end{array}$ & 3.86 \\
\hline 8 & My lending money on credit has increased & $\begin{array}{c}2 \\
1.66\end{array}$ & $\begin{array}{c}58 \\
48.3\end{array}$ & $\begin{array}{c}51 \\
42.5\end{array}$ & $\begin{array}{c}9 \\
7.5\end{array}$ & $\begin{array}{l}0 \\
0\end{array}$ & 3.44 \\
\hline 9 & $\begin{array}{l}\text { Able to invest for purchase of additional goats } \\
\text { and inputs for expansion of farms }\end{array}$ & $\begin{array}{c}2 \\
1.66\end{array}$ & $\begin{array}{c}44 \\
36.6\end{array}$ & $\begin{array}{c}64 \\
53.3\end{array}$ & $\begin{array}{c}13 \\
10.8\end{array}$ & $\begin{array}{l}0 \\
0\end{array}$ & 3.31 \\
\hline 10 & My profit from goat rearing has increased & $\begin{array}{c}2 \\
1.66\end{array}$ & $\begin{array}{l}60 \\
50\end{array}$ & $\begin{array}{l}18 \\
15\end{array}$ & $\begin{array}{c}40 \\
33.3\end{array}$ & $\begin{array}{l}0 \\
0\end{array}$ & 3.2 \\
\hline & Mean score & & & & 4.43 & & \\
\hline
\end{tabular}

Table.2 Distribution of beneficiaries as per Economic Impact

\begin{tabular}{|c|c|c|c|c|}
\hline & \multicolumn{2}{|c|}{ Economic impact } & & Remarks \\
\hline SI.No. & Impact range & Frequency & Percent & Maximum \\
\hline 1 & $\begin{array}{l}\text { High level impact } \\
\begin{array}{c}\text { Mean+1S.D) } \\
>38.41\end{array}\end{array}$ & 22 & 18 & $\begin{array}{l}\text { score }=50 \\
\text { Minimum } \\
\text { score }=10\end{array}$ \\
\hline 2 & $\begin{array}{c}\text { Medium level income } \\
\text { (Mean+ 1S.D)to(Mean- } \\
\text { 1S.D) }\end{array}$ & 83 & 69 & $\begin{array}{c}\text { Mean }=34.43 \\
\text { S.D. }=3.98\end{array}$ \\
\hline 3 & $\begin{array}{l}\text { Low level impact (Mean- } \\
\text { 1S.D) }\end{array}$ & 15 & 13 & \\
\hline
\end{tabular}


The economic contribution of small ruminants to poor farm households and livelihood systems is high. The present study also revealed that the goat rearing has supported poor families in meeting their educational and medicinal expenses at the time of need. Besides, this occupation has helped them to construct additional houses and repayment of loan. Keeping all these beneficial impacts of goat rearing on the livelihood of poor, the Government may take necessary steps to build up capacity of poor farmers on scientific goat rearing to get maximum benefit.

\section{References}

Ahmad S, Fayaz M and Ali G. 2015. An Economic Analysis of Goat Rearing inKohistan District, Khyber Pakhtunkhwa, Journal of Entomology and Zoology studies, 3(3):484-488.

Budisatria IGS and Udob HMJ. 2013. Goat- based aid programme in Central Java: An Effective Intervention for the Poor and Vulnerable?,Small Ruminant Research, 109(1):76-83

Manzi M, Mutabazi J, Hirwa CD and Kugonza DR. 2013. Socio economic Assessment of Indigenous Goat Production System in Rural Areas of Bugesera District in Rwanda, Livestock Research for Rural Development, 25(11): 111116.

Soni RL, Berathi R and Rathore RS. 2011. Socio-economic impact of the Improved Goat Rearing Practices on Tribals, Rajasthan Journal of Extension Education, 19(1): 62-65.

Tuefel N, Kuettner K, Gall C. 1998. Contribution of goat husbandry to household income in the Punjab Pakistan: A Review, Small Ruminant Research, 28(1):101-107

\section{How to cite this article:}

Mohanty, M., B. C. Das and Nanda, S. M. 2020. Economic Impact of Goat Farming on Livelihood of Goat Farmers of Nabarangpur District of Odisha. Int.J.Curr.Microbiol.App.Sci. 9(01): 176-179. doi: https://doi.org/10.20546/ijcmas.2020.901.020 